\title{
The Views and Adoption Levels of Primary School Teachers on Gamification, Problems and Possible Solutions
}

\author{
Hüseyin Yaşar* \\ Department of Computer and Instructional Technologies, Institute of Education Sciences, \\ Sakarya University, Sakarya, Turkey ORCID: 0000-0003-1176-1916 \\ Mübin Kıyıc1 \\ Department of Computer and Instructional Technologies, Institute of Education Sciences, \\ Sakarya University, Sakarya, Turkey, ORCID: 0000-0001-9458-7831
}

\begin{tabular}{|c|c|}
\hline $\begin{array}{r}\text { Department of Co } \\
\text { Ankar } \\
\end{array}$ & $\begin{array}{l}\text { Abuzer Karataş } \\
\text { and Instructional Technologies, Institute of Education Sciences, } \\
\text { ersity, Ankara, Turkey ORCID: 0000-0002-4562-3864 }\end{array}$ \\
\hline Article history & In this research, it is aimed to determine the ideas of primary school \\
\hline $\begin{array}{l}\text { Received: } \\
02.04 .2020\end{array}$ & $\begin{array}{l}\text { teachers about the concept of gamification, the elements of gamification } \\
\text { they use, the criteria they take into consideration while using the elements }\end{array}$ \\
\hline $\begin{array}{l}\text { Received in revised form: } \\
27.06 .2020\end{array}$ & $\begin{array}{l}\text { of gamification, the reasons for using them in gamification, the problems } \\
\text { they face when using gamification and solutions to these problems. } \\
\text { Phenomenology desion a gualitative research desion is referred to in the }\end{array}$ \\
\hline $\begin{array}{l}\text { Accepted: } \\
16.07 .2020\end{array}$ & $\begin{array}{l}\text { research. The participants of the research consist of twelve primary } \\
\text { school teachers who work at different schools and who teach different }\end{array}$ \\
\hline Key words: & grades. In this research, semi-structured interview form, which was \\
\hline $\begin{array}{l}\text { Gamification; } \\
\text { elements of gamification, } \\
\text { usage of gamification, } \\
\text { primary school teachers }\end{array}$ & $\begin{array}{l}\text { prepared by the researchers as a data collecting tool was used. The data } \\
\text { acquired from the interviews done with the participants, was analyzed } \\
\text { through content analysis. According to the results of the research, it was } \\
\text { determined that majority of the primary school teachers perceive the } \\
\text { concept of gamification as an educational game. Badges and leader } \\
\text { boards were determined as the mostly used elements of gamification by } \\
\text { primary school teachers. It was observed that the foremost criteria that } \\
\text { primary school teachers consider while using the elements of } \\
\text { gamification were reading books, starting reading at the first grade and } \\
\text { success level in the lessons. Improving the success of the students and } \\
\text { increasing their motivation in lessons were determined as the reason for } \\
\text { using gamification elements. The foremost problem that primary school } \\
\text { teachers face while the using gamification elements is the over- } \\
\text { competitive behavior occurring amongst the students. As the second, the } \\
\text { problem of regression in the students whose levels are low is stated. As } \\
\text { for solving the problems faced, using the gamification elements taking } \\
\text { into consideration some other actions- not success in lessons- is } \\
\text { determined to be the most effective solution. }\end{array}$ \\
\hline
\end{tabular}

\footnotetext{
*Correspondency: hsyasar@gmail.com, 05057404458
} 


\section{Introduction}

Games attract the interest of individuals of all ages since they have positive effects on participation and motivation of individuals, address human needs and desires, and facilitate the production of solutions to daily life problems (McGonigal, 2011). Throughout human history, different games have been played based on the conditions of the specific time and for different purposes such as entertainment and socialization (Y1lmaz, 2015). In fact, it is known that games are motivating due to the pleasure and satisfaction they generate in an individual and arise the desire to take part in the play all the time (Kuzu \& Çankaya, 2010). Furthermore, as games entail contest and competition, include constructs, and lead to emotional reactions and learning achievements (Kapp, 2012), the interest in educational use of games has increased.

The educational games are organized, and goal-oriented ones played to achieve target acquisitions and develop knowledge and skills (Coşkun, Akarsu \& Kariper, 2012). Although educational games are considered as a form of entertainment, their primary aim is the education of the individual (Noemí \& Máximo, 2014). What is more, game technologies are utilized to acquire target behavior in the instruction process (Ibrahim \& Jaafar, 2011). It was also reported in the literature that educational games had positive effects on the individual. These include the development of a positive attitude (Ke, 2008; Najdi \& Sheikh, 2012), motivation (Braghirolli, Ribeiro, Weise \& Pizzolato, 2016; Dickey, 2011; Wang \& Chen, 2012), learning abstract concepts (Lee \& Hao, 2015), improving achievements (Chen \& Chiu, 2016; Kebritchi, Hirumi \& Bai, 2010) as well as learning performance (Chen \& Chiu, 2016; Najdi \& Sheikh, 2012; Wang \& Chen, 2012).

The positive effects of educational games employed in educational environments led to the development of gamification, which is the utilization of game components in non-gaming environments (Deterding, Dixon, Khaled \& Nacke, 2011). The concept of gamification, first proposed by Nick Pelling in 2003 and the current version of which was adopted in 2010 (Werbach \& Hunter, 2012), has been widely used in several fields such as education, health, communications, transportation, and so on. Kapp (2012) described gamification as the use of game components, game approach and aesthetics in ensuring the commitment of the individual, supporting learning, motivation and problem-solving. Based on another definition, gamification is the use of game approach and game mechanics to raise the interest of the individual and to solve problems (Zichermann \& Cunningham, 2011).

Y1lmaz (2015: 27) stated the difference between game and gamification as follows: The game is an application with goals such as having fun, socializing and learning, and consequences such as winning and losing within a system with specific rules, while gamification is a discipline where gamified designs and game mechanics are added to a non-game process. Thus, it could be suggested that a game is an application whilst gamification is a process where the game components are integrated into non-game environments. Therefore, game, educational game and gamification are different concepts. The main objective in gamification indeed is to effectively implement the positive effects of game components to non-game environments. As stated by Lee \& Hammer (2011), gamification aims to leverage the power of games in solving real-world problems.

Gamification has been classified with several methods in the literature. Marczewski (2015: 15) classified gamification in two groups: internal and external gamification. The internal gamification was described as gamification in behavioral design whereas external 
gamification as adoption of gamification components such as badges and scores in the system. Kapp (2012) classified gamification as structural and content gamification. Kapp reported that the aim of structural gamification was to make use of game components without any changes made in the content, while the content gamification called for gamification of the content. According to Werbach and Hunter (2012), there were three types of gamification viz. internal, external and behavior modifying gamification. The review of gamification classifications demonstrated that the first type of gamification required the inclusion of game components such as rewarding certain behavior in the learning environment using symbolic badges, the use of a scoring system, leader boards that rank the students, and virtual or real rewards. The expression of the content with a gamified approach based on the target achievements in the learning environment reflects the second type of gamification. Kapp (2012) argued that the integration of both types of gamification would lead to more effective outcomes.

Kapp (2012) stated that gamification could be used effectively in content development, motivation, behavioral change, and innovation. Boyce \& Barnes (2010) stated that game components were an important factor for the promotion of motivation and learning. Arkün Kocadere \& Samur (2016) highlighted the positive outcomes of gamification as increase in motivation, entertainment, commitment to the environment and the promotion of instruction based on the data obtained in their study on gamification. They said, certain points should be considered to acquire the positive effects of gamification. Arkün Kocadere \& Samur (2016) reported these points as follows:

"It should not be forgotten that the design could lead to quite different consequences and utilized components should be selected with care and qualified use should be ensured. An application that leads to a sense of flow, commitment, motivation and supports teaching could be employed; however, gamification could also distance students from the learning objectives and lead them to a process where they crush each other to score points without being aware of it."

Thusly, care must be taken in the design of gamified learning environments. It should not be forgotten that the positive effect of gamification depends on the very area of application and the method employed by the users (Hamari, Koivisto \& Sarsa, 2014), and the reward system in gamification could have negative effects on the target after it is discontinued (Werbach \& Hunter, 2012). Therefore, the target audience should be thoroughly checked, and the gamification design components need to be selected depending on the goals. In fact, it was accentutated that the behavior exhibited as a response to the reward system based only on the external motivation could not be transferred, and the behavior could even disappear when the reward is removed from the environment (Domínguez et al., 2013). Thence, it is fair to state that gamification approach is a process that should be designed meticulously, and a welldesigned gamification process could result in positive results, otherwise gamification could fail to produce the desired behavior.

Gamification approach is used actively in every grade i.e. from preschool to college similar to several other fields. Primary education is one of the stages where gamification is used. The red ribbon given to students who start reading is a gamification element used to be employed by classroom teachers for a long time. Today, several badges including "well done," "bookworm," "student of the month," and others are resorted to for various purposes, especially in primary schools. Furthermore, gamification elements such as achievement lists, plus/minus charts, gifts like books and pens, scores are also used by classroom teachers. Whence, the present study aimed to determine the views of classroom teachers on gamification in primary education on the frequently used gamification elements, the criteria 
they prioritize in the employment of gamification elements, the aim of using gamification, problems they encountered in the use of gamification, and their recommendations pertaining to solutions to these problems. To that end, answers to the following research problems were sought:

(1) Do you know the difference between the concepts of game and gamification?

(2) Which gamification elements do you use in your classes?

(3) Which criteria do you employ when using the gamification elements?

(4) For which purposes do you use gamification elements?

(5) What are the problems you experience when using the gamification approach? What are your recommendations to solve these problems?

\section{Method}

\section{The Research Design}

The present study was conducted with phenomenological design, a qualitative research method. The phenomenological approach is a method that allows a detailed and in-depth view of a known phenomenon (Yıldirım \& Şimşek, 2011). The method aims to describe the experiences of individuals or groups in detail (Christensen, Johnson \& Turner, 2015). Hence, the present study was carried out to determine the views of the classroom teachers on gamification and the degree and the purpose of the utilization of gamification applications by these teachers.

\section{Participants}

The participants included classroom teachers employed in various primary schools. In accordance with the aim of the study, classroom teachers employed in different schools and grade levels were selected. In accordance with that the study aimed to improve the diversity of the data collected about the phenomenon. Participant demographics are presented in Table 1.

Table 1. Participant Demographics

\begin{tabular}{lll}
\hline & & $n$ \\
\hline Gender & Female & 6 \\
\hline Age & Male & 6 \\
& $20-30$ & 2 \\
& $31-40$ & 4 \\
\hline Employment (years) & $41-50$ & 4 \\
& $51-60$ & 2 \\
& $6-10$ & 1 \\
& $11-15$ & 2 \\
& $16-20$ & 4 \\
& $21-25$ & 3 \\
& 25 and above & 2 \\
\hline Graduation & Classroom Instruction & 10 \\
& Finance & 1 \\
& Vocational School & 1 \\
\hline Total: & 1st Grade & 4 \\
\hline
\end{tabular}




\section{Data Collection}

In the study, a semi-structured interview form was used to collect the data. The interview form included two sections. The first section included questions to determine the participant demographics. The second part included 5 questions developed catering to the aim of the study. After the authors developed the interview form, it was edited in light of expert opinion obtained from 4 field experts. Then, to test the comprehensibility of the interview form, a pilot scheme was conducted with a classroom teacher and the form was then finalized for implementation. The approval of the relevant institutions was obtained to conduct the interviews and the interviews were carried out in line with the availability of the participating classroom teachers. The participants were informed prior to the interviews about that the collected data would be kept confidential and would not be used for any purposes other than the present study. Interviews were recorded with a voice recorder after the informed consent of the teachers was obtained and transcribed into the Microsoft Word format for data analysis.

\section{Data Analysis}

Content analysis method was used to analyze the transcribed interview documents. Content analysis was described as a systematic, replicable method where certain words in a text are summarized with smaller content categories using codes based on certain criteria (Büyüköztürk et al., 2012, 240). The main objective is to explain the data using the concepts and correlations (Y1ldırım \& Şimşek, 2011). Content analysis is conducted in four stages: data coding, determination of the themes, description and organization of the data based on the codes and themes, and interpretation of the findings. The transcribed interview data were coded by the two authors to determine the themes. Due to the confidential nature of the data, the teachers were assigned codes between P1 and P12. Besides, the inter-coder agreement rate was calculated based on the coding conducted by the two authors. Cohen's kappa inter-coder agreement rate was 0.83; and it was considered good for the study (Landis \& Koch, 1997). The determined codes and themes are presented and interpreted in the findings section of the manuscript. To support the findings, direct participant quotes are also presented (Y1ldırım \& Şimşek, 2011).

\section{Findings}

In this section, the findings on the views of the teachers about the gamification concept, the gamification elements they utilized, the criteria they considered when using gamification elements, their purposes in using the gamification elements and the points that need to be considered when using gamification elements are given.

\section{The Views on the Gamification Concept}

The views of the classroom teachers on the concept of gamification are presented in Table 2.

Table 2. The views of the classroom teachers on the concept of gamification

\begin{tabular}{lll}
\hline Categories & Participants & $\mathrm{n}$ \\
\hline Gamification is educational games & P2, P3, P5, P6, P7, P8, P10, P12 & 8 \\
Accurate knowledge of the gamification concept & P1, P11 & 2 \\
Gamification is gaming & P4, P9 & 2 \\
\hline Total: & & 12 \\
\hline
\end{tabular}


The review of Table 2 demonstrated that 8 participants shared that the concept of gamification was simply associated with educational games, 2 participants articulated the concept simply meant games, and 2 participants had the necessary knowledge of the concept of gamification. The views of the participants P1, P8 and P9 on the gamification concept were as follows:

P1: "Gamification could be described as having fun during the instruction, creation of a competitive environment among the students, and improvement of the focus of the students on the course and their motivation by storifying the topics. Gamification leads to competition during instruction." P8: "Acquisition of educational achievements through games, learning by having fun, and improvement of class participation. In other words, it could be described as the utilization of games for instructional purposes." P9: "Playing games in order to prevent boredom and to improve the focus of the students during classes."

Table 2 demonstrated that there was a misconception about the term of gamification. Although classroom teachers appeared to be utilizing gamification elements, it was observed that they did not really know the actual concept of gamification.

\section{The Utilized Gamification Elements}

Although the concept of gamification was misunderstood by the majority of the interviewed teachers, all 12 teachers stated that they employed gamification elements in their classrooms. The findings on the utilization of gamification elements are indicated in Table 3.

Table 3. The gamification elements utilized by the classroom teachers

\begin{tabular}{lll}
\hline Categories & Participants & $\mathrm{n}$ \\
\hline Badge & P1, P2, P3, P4, P6, P7, P8, P9, P10, P11, P12 & 11 \\
Leaderboard & P1, P2, P3, P4, P6, P7, P8, P9, P10, P11, P12 & 11 \\
Gift & P1, P2, P3, P5, P6, P7, P10, P11 & 8 \\
Avatar & P2, P3, P6, P7, P10, P11, P12 & 7 \\
Storified instruction & P1, P2, P3, P4, P5, P7 & 6 \\
Score & P3, P4, P8, P10, P12 & 5 \\
Reward & P2, P7, P9, P10, P11 & 5 \\
\hline Total: & & 53 \\
\hline
\end{tabular}

The review of Table 3 demonstrated that the gamification elements that were used by the teachers included badges, leaderboards, gifts, avatars, storytelling, scores and rewards. The views of participants P2, P3, P5, P6 and P12 on the gamification elements they utilized are as follows:

P2: "When I check student homework, I put a star on their notebook. I allow the class to applaud students who exhibit exemplary behavior in the classroom. I present weekly reading prince and reading princess cards to 1 female and 1 male student who read and tell about their book. I put a plus next to the name of the students who are successful in the achievement tests on the bulletin board chart. Students could monitor their status on this chart. In addition, I give gifts such as books, pens, etc. to the winners." P3: "I was using the badge "I can read" in the $1^{\text {st }}$ grade. I started using the star of the week badge in the 2nd grade. I select one of my students every week as the star of the week and allow them to wear this badge on their lapels. I give a weekly test about the stories they read, and I award this badge to those who score 90 points or above. Students earn points based on their achievements in classroom. Additionally, I award stars to my students who were successful in the classes and read a lot of books. I display the stars that students earned 
on a starboard. At the end of the year, I give real prizes to students who are the top three in the starboard. I declare the students who are very good at reading books as bookworms in the classroom." P5: "In the first grade, when I was instructing the letters, I would tell a story about each letter. I used to conduct animations about how the letter is pronounced. We use stories a lot, especially for elementary school students to better understand abstract concepts. I awarded the students who started reading with a ribbon. I present a book to successful students in the course. When I conduct reading contests, I present gifts such as pens and books to the top three students." P6: "I use leaderboards in the classroom. The first gets a smiley face with a star. I let the students who participate in the class and with positive behavior one smiley face with a star next to her or his name. I give students the opportunity to paint their smiling faces not only for the success in the course but also for good behavior. Another leader board is the bookworm board. There I write the number of pages that each student reads weekly. I declare that the student who reads the most books is the bookworm of the week. I also reward a plus for completed assignments and a minus for incomplete assignments. When I ask difficult questions in the classroom, I give real rewards to the answering students, including books, notebooks, pens, buckles and wristbands. I also give a real prize to the student who is the winner of the quizzes." P12: "I reward the students who can read with an "I can read" badge. Apart from that, I use the "well done" badge when checking students' homework. I stamp this badge on students' notebooks. I also use the "respectful" badge. I reward students who obey the school and class rules and get along well with their friends with this badge. I use the star badge in each class. For example, I reward it to students who draw beautifully, who have a good voice, who read well. I draw student stars on the starboard. Apart from that, I use a "fry the apple" table. The student, who can read, "fries her/his apple," in other words, paints the apple in red. The student who ranks the first on the starboard is considered the star of the week. I also declare the student, who reads a lot of books, the book monster of the week and hang the picture of this student on the class bulletin board."

The review of Table 3 demonstrated badges and leaderboards were the commonly used gamification elements by classroom teachers. What is more, the use of the storified instruction element was a significant component.

\section{The Criteria Adopted in the Use of the Gamification Elements}

The views of the classroom teachers about the behavior they expected from the students while using gamification elements are documented in Table 4.

Table 4. Gamification Element Use Criteria

\begin{tabular}{lll}
\hline Categories & Participants & $\mathrm{n}$ \\
\hline Reading books & P2, P3, P4, P5, P6, P7, P8, P9, P10, P11, P12 & 11 \\
Starting to read & P1, P2, P3, P4, P5, P7, P8, P10, P11, P12 & 10 \\
Class achievements & P1, P2, P3, P4, P5, P6, P7, P8, P9, P11 & 10 \\
Obeying class rules & P1, P2, P3, P4, P6, P7, P9, P10, P11 & 9 \\
Drawing well & P2, P6, P7, P8, P9, P10, P11, P12 & 8 \\
Checking homework & P1, P2, P4, P6, P9, P10, P11 & 7 \\
Getting along well with peers & P1, P4, P6, P8, P11, P12 & 6 \\
Class participation & P1, P7, P8, P9, P10 & 5 \\
Singing well & P2, P6, P8, P9, P12 & 5 \\
Writing well & P2, P6, P8 & 3 \\
Personal hygiene & P1, P8, P9 & 3 \\
\hline Total: & & 77 \\
\hline
\end{tabular}

The review of Table 4 demonstrated that the most common criterion adopted by the classroom 
teachers when employing gamification elements was reading books. This criterion was followed by starting to read and classroom achievements. The views of the participants P7, P8 and P11 on these criteria are as follows:

P7: "Various criteria should be used during gamification. That's because all students have different traits and skills. So all students should be included in the award system. For example, when I present a reward for a reading race, the student who cannot read well could stop studying for reading thinking that student $A$ was already able to read and would get the reward. But when I reward the number of words that the students read, the same student would spend an effort to earn the reward. Thus, some students are motivated and diligent when rewarded, whether they are making mistakes or not." P8: "I reward the students who succeed in the course, participate in class activities, give the correct answer to questions, get along with their friends, paint beautiful pictures, are successful in gym class, and demonstrate exemplary behavior using stars. I do not only reward achievements in the class but several other behaviors because every student is different. Those who are not successful in the class could paint beautiful pictures, for instance. I pay attention to rewarding all students." P11: "I reward students who exhibit positive behavior, fulfill their responsibilities, comply with the class rules, get along well with their peers with a smiley and let them paint their smiley on the smiley-board. I do this enthusiastically and thank the student to emphasize that the behavior of that student was very important and to indicate that the smiling face was valuable."

As seen in Table 4, gamification elements were also used to ensure that students acquire positive extracurricular behavior.

\section{The Intended Use of Gamification Elements}

The views of classroom teachers on the intended use of gamification elements are presented in Table 5.

Table 5. The intended use of gamification elements

\begin{tabular}{lll}
\hline Categories & Participants & $\mathrm{n}$ \\
\hline Improvement of achievements & $\mathrm{P} 3, \mathrm{P} 4, \mathrm{P} 5, \mathrm{P} 6, \mathrm{P} 7, \mathrm{P} 8, \mathrm{P} 9, \mathrm{P} 10, \mathrm{P} 12$ & 9 \\
Motivation & $\mathrm{P} 1, \mathrm{P} 2, \mathrm{P} 3, \mathrm{P} 4, \mathrm{P} 5, \mathrm{P} 6, \mathrm{P} 9, \mathrm{P} 11, \mathrm{P} 12$ & 9 \\
Competition & $\mathrm{P} 1, \mathrm{P} 2, \mathrm{P} 4, \mathrm{P} 6, \mathrm{P} 9, \mathrm{P} 10, \mathrm{P} 11, \mathrm{P} 12$ & 8 \\
Participation in the classroom & $\mathrm{P} 1, \mathrm{P} 2, \mathrm{P} 3, \mathrm{P} 5, \mathrm{P} 6, \mathrm{P} 9, \mathrm{P} 10$ & 7 \\
Acquisition of positive behavior & $\mathrm{P} 3, \mathrm{P} 4, \mathrm{P} 6, \mathrm{P} 8, \mathrm{P} 9, \mathrm{P} 10, \mathrm{P} 12$ & 7 \\
Improving attention in the class & $\mathrm{P} 2, \mathrm{P} 3, \mathrm{P} 5, \mathrm{P} 6, \mathrm{P} 11$ & 5 \\
Acquisition of reading habit & $\mathrm{P} 4, \mathrm{P} 6, \mathrm{P} 7, \mathrm{P} 8$ & 4 \\
Entertainment & $\mathrm{P} 1, \mathrm{P} 2, \mathrm{P} 3, \mathrm{P} 5$ & 4 \\
Loving the course & $\mathrm{P} 5, \mathrm{P} 10, \mathrm{P} 11$ & 3 \\
Improvement the interest in courses & $\mathrm{P3}, \mathrm{P} 4, \mathrm{P} 8$ & 3 \\
Encouragement & $\mathrm{P} 6$ & 1 \\
Self-esteem & $\mathrm{P} 7$ & 1 \\
\hline Total: & & 61 \\
\hline
\end{tabular}

Table 5 shows that the classroom teachers primarily used gamification elements to improve the student achievements in the class and to motivate the students. The views of the participants P1, P4 and P6 on the intended use of the gamification elements are as follows:

P1: "I use gamification effectively to increase student motivation, participation in the class, and especially to ensure the retention of the stories. By doing so, gamification leads to a nice competition among the students." P4: "Gamification has a significant effect on motivation, increasing course achievements and acquisition of the reading habit." P6: 
"The most important goal in using gamification elements is to increase student achievement. Apart from that, I use it for purposes such as increasing participation, encouraging students, providing competition, ambition, motivation, and improving student attention."

As seen in Table 5, classroom teachers utilized the gamification elements for diverse purposes. It was also observed that gamification elements were used for the adoption of the desired behavior by the students. It was witnessed that gamification elements were used for the acquisition of the habit of reading books and adoption of classroom rules by the students particularly at primary school level. It was suggested that gamification elements could be used effectively in the acquisition of the behavior such as hygiene and nutritional habits along with student achievements in primary schools.

\section{The Problems Experienced in Gamification Element Use}

The views of classroom teachers on the problems they encountered while using gamification elements are presented in Table 6.

Table 6. The problems experienced in gamification element use

\begin{tabular}{lll}
\hline Categories & Participants & $\mathrm{n}$ \\
\hline Jealousy towards peers & P1, P4, P6, P8, P9, P10, P12 & 7 \\
Setbacks in failed students & P4, P6, P8, P9, P10, P11 & 6 \\
Grudge towards peers & P1, P8, P9 & 3 \\
Banalization when used continuously & P2, P7, P9 & 3 \\
Negative reactions towards peers & P2, P6, P10 & 3 \\
Despair and aggrievement & P3, P5, P12 & 3 \\
Harming the gamification elements & P4, P9 & 25 \\
\hline Total: & & \\
\hline
\end{tabular}

As can be seen in Table 6, the most common problem was the jealousy among students. Alongside that the setbacks observed in unsuccessful students was one of the important problems. The views of the participants P7, P10 and P12 on the problems they experienced are below:

P7: "Different criteria should be used in gamification because, students have different traits and skills. All students should be included in the reward system." P10: "Such components have several positive effects. The students study more, participate in the class, love the course, fulfill their responsibilities, and follow the class rules better. However, if you do not address all students, some students experience setbacks. For example, inferiority complex could develop in students who cannot be among the most popular in a week. These students would be jealous of their peers and could exhibit negative behavior towards their friends." P12: "I pay attention to rewarding all students while using them. Otherwise, the students would be upset, inferiority complex develops, and become jealous of their peers."

As seen in Table 6, resolving the above-mentioned problems is crucial for the successful implementation of the gamification approach. The participating classroom teachers suggested numerous solutions that emerged during the gamification process. Solution recommendations proposed by classroom teachers are provided in Table 7. 
Table 7. Solution recommendations proposed by classroom teachers for the problems experienced in gamification applications

\begin{tabular}{|c|c|c|}
\hline Categories & Participants & $\mathrm{n}$ \\
\hline $\begin{array}{l}\text { It should be used for behavior other than academic } \\
\text { achievements }\end{array}$ & $\begin{array}{l}\text { P1, P2, P3, P4, P5, P6, P7, P8, P9, P10, } \\
\text { P11, P12 }\end{array}$ & 12 \\
\hline Planning should include all students & $\mathrm{P} 4, \mathrm{P} 6, \mathrm{P} 7, \mathrm{P} 9, \mathrm{P} 10, \mathrm{P} 11, \mathrm{P} 12$ & 7 \\
\hline $\begin{array}{l}\text { Excessive use of gamification elements should be } \\
\text { avoided }\end{array}$ & $\mathrm{P} 2, \mathrm{P} 7, \mathrm{P} 8, \mathrm{P} 10$ & 4 \\
\hline $\begin{array}{l}\text { Banalization of gamification elements should be } \\
\text { prevented }\end{array}$ & P7, P9 & 2 \\
\hline The rewards should be gradual & $\mathrm{P} 4, \mathrm{P} 7$ & 2 \\
\hline $\begin{array}{l}\text { Acquisition of the student responsibilities should be } \\
\text { targeted }\end{array}$ & P4 & 1 \\
\hline Total: & & 28 \\
\hline
\end{tabular}

The review of Table 7 demonstrated that the most important point that should be taken into account when using gamification elements was the use of gamification elements in areas other than academic achievement. The teachers stated that students should be rewarded for their behavior such as achievements in social courses, acquisition of behavior, and reading books. The views of P8 are as follows:

P8: "Therefore, gamification elements should be planned carefully, and the criteria should include all students. It should not only target academic achievement. If this is planned well, the students would more successful, they would read more books, there would be a mild competition, they would pay more attention to the instructions, follow the rules of hygiene and do their homework regularly."

The second point to bear in mind when using the gamification approach was to include all students. It is necessary to do so and to reward every student for her or his behavior. Or else, the gamification approach would have a negative effect on the non-rewarded students. Participant P4 uttered the following:

P4: "But when gamification is implemented by considering all students, the advantages will be more. On the other hand, it might have negative effects as some of my students did like removing the badges of their peers who have higher number of star badges."

The second point to recall when using the gamification approach was to avoid excessive use of gamification elements. It was pinpointed that rewarding each student's behavior would lead to pudency. Participant P2 stated the following on this issue:

P2: "When I use the storified instruction element of gamification intensively, the students develop shyness. That is why I pay attention to use it sparingly. Such elements should be used not excessively."

The fourth point made by the teaches was the fact that the gamification elements should not be banalized. In order for the awards to remain meaningful for the students, these rewards should be awarded with care. Participant P9 pointed out the following on this issue:

P9: "While I am awarding the rewards, I sometimes make changes so that students do not get used to it. For example, I may select the student who gives a different answer to the questions I ask. Or I can reward the students who pay attention to their responsibilities."

Awarding the prizes gradually was the fifth point made by the teachers. When a behavior is to 
be rewarded, the student should not be expected to be completely successful. Gradual awarding should be adopted instead. Participant P7 emphasized the following on the issue:

P7: "For example, when I give a reward for the reading race, the student who cannot read well could stop studying because she or he thinks that student A would get the reward since she/he is already able to read well. But when I reward them based on the number of the words they read, the same student would try to earn a reward."

The final point to be considered when using gamification elements was the fact that the awards should be presented to develop the sense of responsibility amongst the students. It is fundamental for the students to internalize the rewarded behavior.

P4: "I have different ideas about rewards. I do not reward students for behaviors such as doing homework. I would reward these at the beginning, but my aim is the internalization of student responsibilities. Then, I reward the extra efforts in homework.

\section{Discussion}

It was observed that the majority of the participants had inaccurate information about the concept of gamification in the present study that aimed to determine the level of knowledge of the teachers about the concept of gamification, the gamification elements they used, the utilization criteria, the intended use, the problems they encountered and the solution suggestions for the problems they encountered. Participants confused gamification with educational games and considered the concept as educational games that allow students to learn while having fun. Only some participants were aware of the true meaning of the concept of gamification that gamification was the use of game elements in non-game environments where the aim does not entail the game itself. In previous studies and applications in the literature, it was reported that there was a misconception about gamification and educational games, in particular for game-based learning concepts (Sezgin, Bozkurt, Y1lmaz, \& Linden, 2018). In the meta-analysis conducted by Özkan \& Samur (2017), it was concluded that there was a misconception about the concepts of gamification and game-based learning.

It was determined that badges and leaderboards were the most employed gamification elements by classroom teachers. Karataş (2014) announced that the most used gamification elements included badges, scores and leaderboards in a meta-analysis study on gamification. It was reported by Lister (2015) that the badges and leaderboards were the most widely used gamification elements in gamified environments. In the meta-analysis conducted by Özkan \& Samur (2017), it was concluded that the most employed game components were scores, levels, awards and badges, respectively. Özgür, Çuhadar \& Akgün (2018) found that the most adopted gamification elements were scores, badges and leaderboards in their meta-analysis. The present study findings obtained from the views of classroom teachers were consistent with the previous studies in the literature. Together with these, gamification elements such as gifts, avatars, storytelling, scores and prizes were used by classroom teachers. Specifically, in the first grade, the use of 'I can read' ribbons, stars, 'well done' badges, and others have been common for a long period of time and used by almost all classroom teachers. Plus, it was observed that leaderboards were used by classroom teachers for various purposes. Classroom teachers have been using the gamification approach and various gamification elements actively in their classes even though they do not know the actual meaning of the concept.

It was observed that the habit of reading books was the leading gamification element used by the classroom teachers. It was determined that all the classroom teachers, except for one 
participant, rewarded the book reading behavior. The acquisition of book reading habit by the students at primary school level was considered necessary by the classroom teachers and supported by gamification elements. Acquisition of reading skills in the first year and academic achievement ranked the second according to the views of classroom teachers. Also, obeying the classroom rules was determined as a behavior that was valued and rewarded by most classroom teachers.

The primary objectives of classroom teachers when using gamification elements were to improve academic achievements and motivation of the students. The review of the literature on gamification demonstrated that several studies emphasized motivation and achievements (Sezgin, 2016). Özcan (2019) declared that gamification had a positive effect on academic achievement and motivation in a meta-analysis study. It was underlined in the literature that the gamification use had positive effects (Hamari et al., 2014; Hanus \& Fox, 2015; Kapp, 2012; Werbach \& Hunter, 2012). That being said, creating competition among students, ensuring their participation in the class and acquisition of positive behavior were among the objectives of the majority of classroom teachers when using gamification elements.

The most common problem experienced in gamification applications was the jealousy that students exhibited towards their peers. Student behavior such as setbacks, grudge against their peers, banalization, negative behavior towards their peers, despair, sadness, and physical damage to gamification elements were also identified. Arkün Kocadere \& Samur (2016) reported that gamification design may steer out of purpose and could lead to negative outcomes in cases where the gamification design is not conducted with care. Şenocak \& Bozkurt (2020) reported that balance should be maintained in gamification systems and design should not be allowed to override the context.

The common solution proposed for the problems faced in the use of gamification elements by all participants was the implementation of gamification elements based on several behavior and not limited to academic achievement. Consideration of the traits of each student and allowing the whole class to benefit from the gamification elements were among the proposed solutions. It was reported that player types could be used as a new learning criterion for individual differences in game-based educational environments (Sezgin, 2020). Şenocak \& Bozkurt (2020) underpinned the necessity to select the most suitable player type and utilize gamification elements that would appeal to each player type in gamification. Sezgin et al. (2018) reported that attention should be paid to the adaptation of gamification in learning environments based on the learners. Similarly, Hamari et al. (2014) reported that the positive impact of gamification depends on the way the individual adopts it. Careful and pertinent use of the gamification elements, avoiding excessive use and rewarding every behavior, and prevention of banalizing the gamification elements, gradual use of the gamification elements, and using the gamification elements for the purpose of internalization of the behavior, that is, aiming the acquisition of responsibility by the students, were the other solutions suggested by the classroom teachers.

\section{Conclusion and Recommendations}

In conclusion, although the majority of classroom teachers did not know the actual meaning of gamification in the present study, it was revealed that they actively employed several gamification elements in their classes. It was discovered that the badges and leaderboards were the mostly employed gamification elements by the classroom teachers and the behavior considered the most when employing gamification elements was reading books. 
It was found that gamification elements were mostly used to improve student achievement and motivation. The most frequent problems experienced by classroom teachers when using gamification elements were jealousy among students and setbacks among unsuccessful students who failed to receive awards. The solutions suggested by the teachers to resolve these problems included the employment of gamification elements for purposes other than academic achievement and planning the gamification elements based on the traits of all students in the classroom. Based on the study findings, the following recommendations were determined:

- Face-to-face or online seminars, courses, training and alike could be organized by related institutions for teachers to recognize the similarities and differences between the concepts of gaming, educational games and gamification.

- It was observed that various problems were encountered in the employment of the gamification approach. To refrain from these, it could be suggested that classroom teachers develop gamification elements based on the individual student traits in the learning environment.

- When using gamification elements, it could be suggested that gamification elements should be integrated after considerable and detailed planning to avoid boredom and banalization of the gamification elements.

- Gamification planning was suggested to include academic, cultural, artistic, and sportive behavior for the success of the gamification process combined with academic achievements.

\section{References}

Arkün Kocadere, S., \& Samur, Y. (2016). From Game to Gamification In A. İşman, H. F. Odabaş1, \& B. Akkoyunlu (Eds.), Educational Technology Readings 2016 (pp. 397415). Ankara: Salmat Publising.

Boyce, A., \& Barnes, T. (2010). BeadLoom Game: Using Game Elements to Increase Motivation and Learning. Proceedings of the Fifth International Conference on the Foundations of Digital Games - FDG '10, 25-31. https://doi.org/10.1145/1822348.1822352

Braghirolli, L. F., Ribeiro, J. L. D., Weise, A. D., \& Pizzolato, M. (2016). Benefits of educational games as an introductory activity in industrial engineering education. Computers in Human Behavior, 58, 315-324. https://doi.org/10.1016/j.chb.2015.12.063

Chen, C. H., \& Chiu, C. H. (2016). Employing intergroup competition in multitouch designbased learning to foster student engagement, learning achievement, and creativity. Computers and Education, 103, 99-113. https://doi.org/10.1016/j.compedu.2016.09.007

Christensen, L. B., Johnson, R. B., \& Turner, L. A. (2015). Research Methodology: Design and Analysis. Ankara: Anı Publising.

Coşkun, H., Akarsu, B., \& Kariper, İ. A. (2012). The Effects of Educational Games based on Science Stories on Students' Academic Achievements in Science and Technology Classroom. Journal of Ahi Evran University Kirşehir Faculty of Education, 13(1), 93109.

Deterding, S., Dixon, D., Khaled, R., \& Nacke, L. (2011). From game design elements to gamefulness. Proceedings of the 15th International Academic MindTrek Conference on Envisioning Future Media Environments - MindTrek '11. https://doi.org/10.1145/2181037.2181040 
Dickey, M. D. (2011). Murder on Grimm Isle: The impact of game narrative design in an educational game-based learning environment. British Journal of Educational Technology, 42(3), 456-469. https://doi.org/10.1111/j.1467-8535.2009.01032.x

Domínguez, A., Saenz-De-Navarrete, J., De-Marcos, L., Fernández-Sanz, L., Pagés, C., \& Martínez-Herráiz, J. J. (2013). Gamifying learning experiences: Practical implications and outcomes. Computers and Education, 63, 380-392. https://doi.org/10.1016/j.compedu.2012.12.020

Hamari, J., Koivisto, J., \& Sarsa, H. (2014). Does gamification work? - A literature review of empirical studies on gamification. Proceedings of the Annual Hawaii International Conference on System Sciences, 3025-3034. https://doi.org/10.1109/HICSS.2014.377

Hanus, M. D., \& Fox, J. (2015). Assessing the effects of gamification in the classroom: A longitudinal study on intrinsic motivation, social comparison, satisfaction, effort, and academic performance. Computers and Education, 80, 152-161. https://doi.org/10.1016/j.compedu.2014.08.019

Ibrahim, R., \& Jaafar, A. (2011). User acceptance of educational games: A revised unified theory of acceptance and use of technology (UTAUT). World Academy of Science, Engineering and Technology, 77(5), 551-557.

Kapp, K. M. (2012). The gamification of learning and instruction: game-based methods and strategies for training and education. John Wiley \& Sons.

Karataş, E. (2014). Gamification in Education: Research Trends. Journal of Ahi Evran University Kirşehir Faculty of Education, 15(2), 315-333.

Ke, F. (2008). Computer games application within alternative classroom goal structures: cognitive, metacognitive, and affective evaluation. 539-556. https://doi.org/10.1007/s11423-008-9086-5

Kebritchi, M., Hirumi, A., \& Bai, H. (2010). The effects of modern mathematics computer games on mathematics achievement and class motivation. Computers and Education, 55(2), 427-443. https://doi.org/10.1016/j.compedu.2010.02.007

Kuzu, A., \& Çankaya, S. (2010). Transformations in the Game. In F. Odabaşı (Ed.), Transformations in the Light of Information and Communication Technologies. Nobel Publishing.

Lee, L. C., \& Hao, K. C. (2015). Designing and evaluating digital game-based learning with the arcs motivation model, humor, and animation. International Journal of Technology and Human Interaction. https://doi.org/10.4018/ijthi.2015040105

Marczewski, A. (2015). Even Ninja Monkeys Like to Play: Gamification, Game Thinking and Motivational Design. CreateSpace Independent Publishing Platform.

McGonigal, J. (2011). Reality Is Broken (1st ed.). Newyork: The Penguin Press.

Najdi, S., \& Sheikh, R. El. (2012). Educational Games: Do They Make a Difference? Procedia - Social and Behavioral Sciences, 47, 48-51. https://doi.org/10.1016/j.sbspro.2012.06.612

Noemí, P.-M., \& Máximo, S. H. (2014). Educational games for learning. Universal Journal of Educational Research, 2(3), 230-238. https://doi.org/10.13189/ujer.2014.020305

Özcan, Ş. (2019). A Meta-Analysis Study on the Researches on Gamification In Education. Master Thesis. Firat University, Institute of Educational Science.

Özkan, Z. \& Samur, Y. (2017). The Effect of Using Gamification on Students' Motivation. Ege Journal of Education, 18(2), 857-886.

Özgür, H., Çuhadar, C., \& Akgün, F. (2018). Current Trends in Gamification Research in Education. Kastamonu University Kastamonu Education Journal, 26(5), 1-9. https://doi.org/10.24106/kefdergi.380982

Sezgin, S., Bozkurt, A., Y1lmaz, E. A., \& Linden, N. van der. (2018). Gamification, Education And Theoretical Approaches: Motivation, Engagement And Sustainability In Learning 
Processes. Mehmet Akif Ersoy University Journal of Education Faculty, (45), 169189. https://doi.org/10.21764/ maeuefd.339909

Sezgin, S. (2020). Digital Player Typologies in Gamification and Game-Based Learning Approaches: A Meta-Synthesis. Bartin University Journal of Faculty of Education, 9(1), 49-68. https://doi.org/10.14686/buefad.610524

Şenocak, D. \& Bozkurt, A. (2020). Gamification, Player Types and Gamification Design Frameworks. Journal of Open Education Practices and Research, 6(1), 78-96.

Wang, L. C., \& Chen, M. P. (2012). Effects of the sequence of game-play and game-design on novices' motivation, flow, and performance. Lecture Notes in Computer Science (Including Subseries Lecture Notes in Artificial Intelligence and Lecture Notes in Bioinformatics), 7220 LNCS, 46-55. https://doi.org/10.1007/978-3-642-31439-1_5

Werbach, K., \& Hunter, D. (2012). For the win: how game thinking can revolutionize your business. Philadelphia: Wharton Digital Press.

Yıldırım, A., \& Şimşek, H. (2011). Qualitative research methods in the social sciences (8th ed.). Ankara: Seçkin Publishing

Y1lmaz, E. A. (2015). Gamification (1st ed.). Abaküs Publishing

Zichermann, G., \& Cunningham, C. (2011). Gamification by design: Implementing game mechanics in web and mobile apps. Sebastopol: O'Reilly Media Inc. 